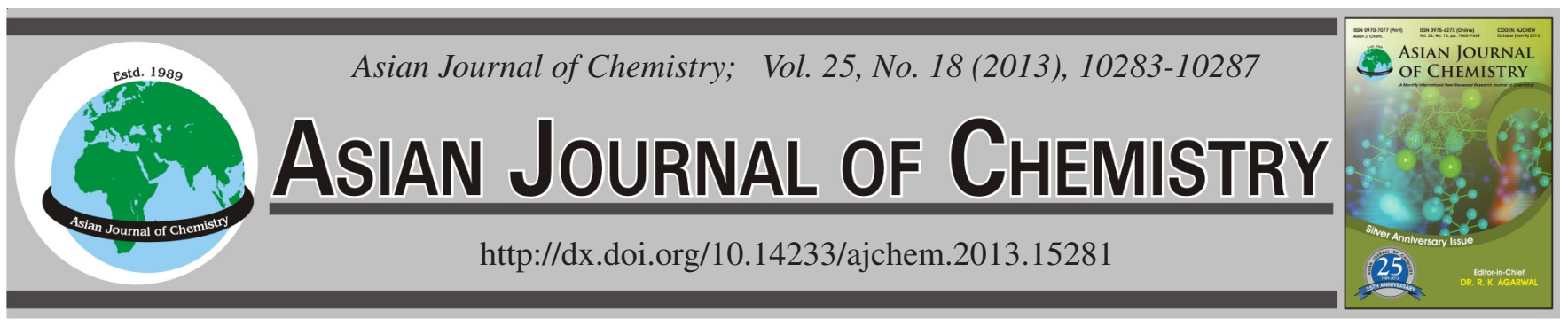

\title{
Electrochemical Generation of Cyano Ligated Molybdenum Sulphur Tetramer Cubane Core: Synthesis and Characterization
}

\author{
AnAmika ${ }^{1}$, RAmJeE $\mathrm{SAH}^{2}$ and Ashwini Kumar ${ }^{3, *}$
}

${ }^{1}$ Department of Chemistry, Mahila College, Chaibasa-833 201, India

${ }^{2}$ University Department of Chemistry, B.R.A. Bihar University Muzaffarpur-842 001, India

${ }^{3}$ Department of Chemistry, Shyam Nandan Sahay College, Muzaffarpur-842 001, India

*Corresponding author: E-mail: ashwinikumar.chem@gmail.com

\begin{abstract}
For the first time the conversion of trimeric $\left\{\mathrm{M}_{3} \mathrm{~S}_{4}\right\}^{4+}$ to tetrameric $\left(\mathrm{M}_{4} \mathrm{~S}_{4}\right\}^{4+}$ core has been made for molybdenum complex. The complex, $\left.\mathrm{K}_{5}\left[\mathrm{Mo}_{3} \mathrm{~S}_{4} \mathrm{CN}\right)_{9}\right](\mathbf{1})$ on using with strong reducing agent transformed into $\mathrm{K}_{8}\left[\mathrm{Mo}_{4} \mathrm{~S}_{4}(\mathrm{CN})_{12}\right](2)$ in near quantitative yield. The diamagnetic complex (1) containing $\left\{\mathrm{Mo}_{3}\right\}^{6}$ core can accommodate two electrons in its non bonding molecular orbital $2 \mathrm{a}_{1}$ under reducing environment to give a complex ion $\left[\mathrm{Mo}_{3} \mathrm{~S}_{4}(\mathrm{CN})_{9}\right]^{7-}$ with $\left[\mathrm{Mo}_{3}\right]^{8}$ electronic configuration. This reduced species undergoes re-oxidation by atmospheric air to give back the original compound with $\left[\mathrm{Mo}_{3}\right]^{6}$ core via a partially oxidized an intermediate species $\left[\mathrm{Mo}_{3} \mathrm{~S}_{4}(\mathrm{CN})_{9}\right]^{6-}$ with $\left[\mathrm{Mo}_{3}\right]^{7} \mathrm{core}$ shows a characteristic EPR signal. However, under drastic reducing condition, the two electrons reduced species $\left[\mathrm{Mo}_{3} \mathrm{~S}_{4}(\mathrm{CN})_{9}\right]^{7-}$ with $\left[\mathrm{Mo}_{3}\right]^{8}$ core accommodate the next coming electron to its antibonding $2 \mathrm{e}$ orbital and thus achieve an unstable tri-nuclear $\left[\mathrm{Mo}_{3}(\mathrm{III})\right]^{9} \mathrm{core}$, where each metal centre has been reduced by one electron. The highly unstable and super reduced species $\left[\mathrm{Mo}_{3} \mathrm{~S}_{4}(\mathrm{CN})_{9}\right]^{8-}$ with $\left[\mathrm{Mo}_{3}(\mathrm{III})\right]^{9}$ configuration undergoes core transformation from cuboidal trinuclear $\left[\mathrm{Mo}_{3}(\mathrm{IV}) \mathrm{S}_{4}\right]^{4+}$ to the cubane type tetranuclear core $\left[\mathrm{Mo}_{4}(\mathrm{III}) \mathrm{S}_{4}\right]^{4+}$ of $\left[\mathrm{Mo}_{4} \mathrm{~S}_{4}(\mathrm{CN})_{12}\right]^{8-}$ complex ion. The corresponding tungsten-analogue though responses this reduction, but quickly oxidizes back to the starting material during work-up procedure.
\end{abstract}

Key Words: Electro-chemical generation, Tetramer, Tetra-nuclear cubane type, Molybdenum-sulphur cluster.

\section{INTRODUCTION}

Triangular $\mathrm{Mo}_{3} \mathrm{O}_{4}{ }^{4+}$ ion containing species have electronprecise six cluster electrons for the set of three Mo-Mo bonds in the $\left\{\mathrm{Mo}_{3}(\mathrm{IV})\right\}^{6}$ core ${ }^{1-4}$. Proton coupled reductions for compounds containing this ion involve two sequential electron transfer steps to yield $\left\{\mathrm{Mo}_{3}\right\}^{8}$ and $\left\{\mathrm{Mo}_{3}\right\}^{9}$ with the absence of $\left\{\mathrm{Mo}_{3}\right\}^{7}$ core $^{4-6}$. Complex of eight or nine cluster electrons containing $\mathrm{Mo}_{3} \mathrm{OCl}_{3}$ moiety have been reported ${ }^{3}$. For the related $\mathrm{Mo}_{3} \mathrm{~S}_{4}{ }_{4}^{4+}$ ion containing complex, the redox reaction are extremely varied. Thus for $\left.\left[\mathrm{Mo}_{3}(\mathrm{IV}) \mathrm{S}_{4} \mathrm{HN}\left(\mathrm{CH}_{2} \mathrm{CO}_{2}\right)_{2}\right\}_{3}\right]^{2-}$, three sequential electron transfer steps in its reduction has been reported relatively at very low negative potential in water ${ }^{6,7}$ compared to the our step, i.e., reduction of $\left[\mathrm{Mo}_{3}(\mathrm{IV}) \mathrm{S}_{4}(\mathrm{CN})_{9}\right]^{5-}$ at very high negative potential in dimethyl sulphoxide $\mathrm{e}^{7-9}$. This large difference in reduction potential may not solely be due to the effect of peripheral ligands in these complex.

Formation of heterometal cubane $\left\{\mathrm{M}^{\prime} \mathrm{Mo}_{3} \mathrm{~S}_{4}\right\}^{\mathrm{n}+}$ core has been made by reacting $\left[\mathrm{Mo}_{3} \mathrm{~S}_{4}\left(\mathrm{H}_{2} \mathrm{O}\right)_{9}\right]^{4+}$ ion with metal in acidic medium under the inert atmosphere of nitrogen ${ }^{10-12}$. Interestingly by following magnesium, tin, or mercury, as reducing agent, double cubane $\left[\mathrm{Mo}_{6} \mathrm{~S}_{8}\left(\mathrm{H}_{2} \mathrm{O}\right)_{18}\right]^{8+},\left[\mathrm{Sn} \cdot \mathrm{Mo}_{6} \mathrm{~S}_{8}\left(\mathrm{H}_{2} \mathrm{O}\right)_{18}\right]^{8+}$ and $\left[\mathrm{HgMo}_{6} \mathrm{~S}_{8}\left(\mathrm{H}_{2} \mathrm{O}\right)_{18}\right]^{8+}$, have also been synthesized ${ }^{13-15}$. These are similar to the hetero double cubane of Fe-Mo-S system made as model for nitrogenase enzyme ${ }^{16-18}$ and using this strategy for the first time ammonia coordinated cubane, has also been synthesized ${ }^{19}$.

Regeneration of complete homo metal cubane $\left[\mathrm{Mo}_{4} \mathrm{~S}_{4}\left(\mathrm{H}_{2} \mathrm{O}\right)_{12}\right]^{5+}$ achieved by the reduction of $\left[\mathrm{Mo}_{3} \mathrm{~S}_{4}\left(\mathrm{H}_{2} \mathrm{O}\right)_{9}\right]^{4+}$ and $\left[\mathrm{Mo}\left(\mathrm{H}_{2} \mathrm{O}\right)_{6}\right]^{3+}$ with $\mathrm{NaBH}_{4}$ in $0.3 \mathrm{M} \mathrm{HCl}$ under nitrogen atmosphere. However, this cubane cluster containing $\left\{\mathrm{Mo}_{4} \mathrm{~S}_{4}\right\}^{\mathrm{n}+}$ core gets slowly revert back to the starting material $\left[\mathrm{Mo}_{3} \mathrm{~S}_{4}\left(\mathrm{H}_{2} \mathrm{O}\right)_{9}\right]^{4+}$ on keeping in air for several days. The entire inter conversion of $\left\{\mathrm{Mo}_{3} \mathrm{~S}_{4}\right\}^{4+}$ core to $\left\{\mathrm{Mo}_{4} \mathrm{~S}_{4}\right\}^{4+}$ core under drastic reducing atmosphere have been reported where sometimes it gets also inter convert to the heterometallic or homometallic double cubane core like $\left[\mathrm{M}^{\prime} \mathrm{Mo}_{6} \mathrm{~S}_{8}\left(\mathrm{H}_{2} \mathrm{O}\right)_{18}\right]^{8+}$ or $\left[\mathrm{Mo}_{6} \mathrm{~S}_{8}\left(\mathrm{H}_{2} \mathrm{O}\right)_{18}\right]^{8+}$ complex, respectively ${ }^{13-19}$

Though the complex $\mathrm{K}_{8}\left[\mathrm{Mo}_{4} \mathrm{~S}_{4}(\mathrm{CN})_{12}\right] \cdot 4 \mathrm{H}_{2} \mathrm{O}(2)$ has been isolated in poor yield $(2.5 \%)$ long back as by-product of $\mathrm{K}_{5}\left[\mathrm{Mo}_{3} \mathrm{~S}_{4}(\mathrm{CN})_{9}\right] \cdot 5 \mathrm{H}_{2} \mathrm{O}(\mathbf{1})$ by Muller and co-worker ${ }^{19}$. It is a time taking long process and require 7 days for its complete 
synthesis. Here, authors wish to describe an easy procedure for the synthesis of complex (2) in near quantitative yield by the reduction of (1) obtained as a product after cyanolysis of $\left(\mathrm{NH}_{4}\right)_{2}\left[\mathrm{Mo}_{3} \mathrm{~S}_{13}\right]$ with strong reducing agents like $\mathrm{Na} / \mathrm{Hg}$ or $\mathrm{NH}_{2} \mathrm{NH}_{2} \cdot \mathrm{H}_{2} \mathrm{O}$ is presence of $\mathrm{KCN}$.

\section{EXPERIMENTAL}

IR spectra of these complexes were recorded on PerkinElmer model 580 infrared spectrophotometer. Samples were prepared as CsI pellets and referenced to polystyrene bands. The electronic spectra of complexes were recorded on Shimadzu. UV-VIS 190 and Perkin-Elmer $\lambda_{2}$ double beam spectrophotometers using matched quartz cell. EPR spectra were obtained from varian-E-109 using DPPH.

The cyclic voltammograms were recorded on a Bioanalytical system CV-27 voltammogramm, in the connection with a C1B-Cell stand. All the experiments were performed in a standard three electrode configuration using an auxiliary Ptelectrode, a glassy carbon working electrode and a saturated calomel electrode under dry nitrogen atmosphere. All results were collected at $298 \mathrm{~K}$ and referenced to saturated calomel electrode (SCE). Distilled and dry DMSO was used as a solvent. $\left[\left(\mathrm{C}_{2} \mathrm{H}_{5}\right)_{4} \mathrm{NClO}_{4}\right]$ and $\mathrm{KCl}, \mathrm{KOH}-\mathrm{KCN}, \mathrm{KOH}-\mathrm{KCN}$ $\mathrm{K}_{2}\left[\mathrm{Zn}(\mathrm{CN})_{4}\right]$ were used as supporting electrolyte for nonaqueous and aqueous medium, respectively. The reported values were uncorrected for junction potential where voltammograms were recorded in different scan speeds with the scan speed at $100 \mathrm{mV} / \mathrm{s}$. The X-ray powder patterns were recorded on a Siefert-isodebyeflex-2002 diffractrometer using $\mathrm{CuK}_{\alpha}$ radiation with $\mathrm{Ni}$-filter. The powdered sample was packed on a perspex sample holder.

All reagents and solvents were of A.R. grade and were used without further purification. Water was distilled in quickfit apparatus over allkaline $\mathrm{KMnO}_{4}$ and $\mathrm{H}_{2} \mathrm{SO}_{4}$. The electric conductance of distilled water varied between $7 \times 10^{-7}-9 \times 10^{-9}$ $\mathrm{W}^{-1} \mathrm{~cm}^{-1}$. The compound $\mathrm{K}_{5}\left[\mathrm{Mo}_{3} \mathrm{~S}_{4}(\mathrm{CN})_{9}\right]$ was prepared from $\left(\mathrm{NH}_{4}\right)_{2}\left[\mathrm{Mo}_{3} \mathrm{~S}_{13}\right]$ by the reported methods ${ }^{19}$. All experiments were carried out under nitrogen atmosphere with degassed distilled water. Chemicals like $\mathrm{KCN}, \mathrm{NH}_{2} \mathrm{NH}_{2} \cdot \mathrm{H}_{2} \mathrm{O}$ and Alpowder were used as purchased. Elemental analyses were performed by EA-1108 elemental analyzer. Sulphur and molybdenum were analyzed by oxidizing the compound under peroxide fusion as $\mathrm{BaSO}_{4}$ and molybdenum oxinate, respectively.

\section{Synthesis of $\mathrm{K}_{8}\left[\mathrm{Mo}_{4} \mathrm{~S}_{4}(\mathrm{CN})_{12}\right] \cdot 4 \mathrm{H}_{2} \mathrm{O}$}

Method A: Conversion of trimer $\left\{\mathrm{Mo}_{3} \mathrm{~S}_{4}\right\}^{4+}$ core to a tetramer $\left\{\mathrm{Mo}_{4} \mathbf{S}_{4}\right\}^{4+}$ core in solution: $\left(\mathrm{NH}_{4}\right)_{2}\left[\mathrm{Mo}_{3} \mathrm{~S}_{13}\right](370 \mathrm{mg}$; $0.5 \mathrm{mmol})$ and $\mathrm{KCN}(2.0 \mathrm{~g}$ : $30 \mathrm{mmol})$ were taken in $30 \mathrm{~mL}$ water and warmed up to $60-70{ }^{\circ} \mathrm{C}$ for $0.5 \mathrm{~h}$. A bright green solution of $\mathrm{K}_{5}\left[\mathrm{Mo}_{3} \mathrm{~S}_{4}(\mathrm{CN})_{9}\right] \cdot 2 \mathrm{H}_{2} \mathrm{O}$ identified by $\mathrm{UV}$-visible spectra. To this complex, $\mathrm{KOH}(2.0 \mathrm{~g}) ; \mathrm{KCN}$ (650 mg; 10 mmol) and $\mathrm{NH}_{2} \mathrm{NH}_{2} \mathrm{H}_{2} \mathrm{O}(1 \mathrm{~mL})$ were added. The resultant solution was allowed to warm slowly. The colour changed from green to red in the period of $15 \mathrm{~min}$. The solution was kept warm $\left(70^{\circ} \mathrm{C}\right)$ for $1 \mathrm{~h}$ and then allowed to cool. The red solution produce on slow evaporation needle shaped red crystalline product which was isolated in ( $c a .65 .5 \%)$ yields good based on the starting materials. Anal. calcd. (\%) for $\mathrm{K}_{8}\left[\mathrm{Mo}_{4} \mathrm{~S}_{4}(\mathrm{CN})_{12}\right] \cdot 4 \mathrm{H}_{2} \mathrm{O}$. Calcd (found) (\%): C: 12.16 (12.06);
H: 0.675 (0.708); N: 14.19 (14.24); S: 10.81 (10.50); Mo: 32.43 (32.12).

Method B: Conversion of a trimer $\left\{\mathrm{Mo}_{3} \mathrm{~S}_{4}\right\}^{4+}$ core to a tetramer $\left\{\mathrm{Mo}_{4} \mathrm{~S}_{4}\right\}^{4+}$ core using a solid state reaction: $\mathrm{A}$ thoroughly mixed powder mixture containing $\mathrm{K}_{5}\left[\mathrm{Mo}_{3} \mathrm{~S}_{4}(\mathrm{CN})_{9}\right]$. $2 \mathrm{H}_{2} \mathrm{O}$; $(880 \mathrm{mg} ; 1 \mathrm{mmol})$; KCN (2.0 g; $\left.30 \mathrm{mmol}\right)$ and $\mathrm{KSCN}$ $(10 \mathrm{~g})$ was heated up to $250{ }^{\circ} \mathrm{C}$ in a closed vessel under dry nitrogen atmosphere on an oil bath. The green colour of starting material started changing to brown and finally stopped to red. The temperature at $250^{\circ} \mathrm{C}$ was maintained for $1 \mathrm{~h}$. After cooling down the red product, it was washed thoroughly with excess of $\mathrm{MeOH}-\mathrm{H}_{2} \mathrm{O}$ mixture, to remove excess of potassium salt as impurity. Then the product was dissolved in the minimum amount of water and finally allowed to slow evaporation. A red needle-shaped crystalline product was isolated in $70 \%$ yield based on the starting material $\mathrm{K}_{5}\left[\mathrm{Mo}_{3} \mathrm{~S}_{4}(\mathrm{CN})_{9}\right] \cdot 2 \mathrm{H}_{2} \mathrm{O}$ and characterized as $\mathrm{K}_{8}\left[\mathrm{Mo}_{4} \mathrm{~S}_{4}(\mathrm{CN})_{12}\right] \cdot 4 \mathrm{H}_{2} \mathrm{O}$.

\section{RESULTS AND DISCUSSION}

IR-Spectrum of product obtained as $\mathrm{K}_{8}\left[\mathrm{Mo}_{4} \mathrm{~S}_{4}(\mathrm{CN})_{12}\right]$. $4 \mathrm{H}_{2} \mathrm{O}$ shows vibration at $2123 \mathrm{~cm}^{-1}$ for $\mathrm{vCN}, 1620(\mathrm{~m})$ for $\delta \mathrm{H}_{2} \mathrm{O}, 3490$ (s) and 3570(s) for $\mathrm{vH}_{2} \mathrm{O}, 370,340,310$ and at 228 $\mathrm{cm}^{-1}$ for $\mathrm{vMo}-\mathrm{S}$ and Mo-Mo. The various physico-chemical characterization of synthesized complex suggest that it is identical to that reported earlier as $\mathrm{K}_{8}\left[\mathrm{Mo}_{4} \mathrm{~S}_{4}(\mathrm{CN})_{12}\right] \cdot 2 \mathrm{H}_{2} \mathrm{O}$ which has already been well characterized by Muller and co-workers using several physical measurements ${ }^{19}$.

IR spectral data: IR-spectrum of product obtained shows vibration at $2123 \mathrm{~cm}^{-1}$ for $\mathrm{v}(\mathrm{CN}), 1620(\mathrm{~m})$ for $\delta \mathrm{H}_{2} \mathrm{O}, 3490 \mathrm{~s}$ and $3570 \mathrm{~s}$ for $\mathrm{vH}_{2} \mathrm{O}, 370,340,310$ and $228 \mathrm{~cm}^{-1}$ for $v \mathrm{Mo}-\mathrm{S}$ and $v$ Mo-Mo.

According to the X-ray structure analysis $\left[\mathrm{Mo}_{4} \mathrm{~S}_{4}(\mathrm{CN})_{12}\right]^{8-}$ has practically $\mathrm{T}_{\mathrm{d}}$ symmetry. In spite of the high symmetry of this complex, the assignment of IR and Raman spectra is not so easy according to the large number of vibrational degree of freedom $(3 n-6=90)$. The analysis was extended to the complete species $\left[\mathrm{Mo}_{4} \mathrm{~S}_{4}(\mathrm{CN})_{12}\right]^{8-}$ by including the M-C-N linear bending and $\mathrm{C}-\mathrm{N}$ stretching. The normal modes of vibrations are distributed among the symmetry species of the $T_{d}$ group according to

$$
\Gamma_{\text {vib }}=6 \mathrm{~A}_{1}(\mathrm{R})+2 \mathrm{~A}_{2}+8 \mathrm{E}(\mathrm{R})+9 \mathrm{~T}_{1} 13 \mathrm{~T}_{2}(\mathrm{R}, \mathrm{IR})
$$

The designations are explained in the following manner, where the multiplicity of each type is shown in parenthesis: $\mathrm{d}=\mathrm{MC}$ stretching (12), $\gamma=\mathrm{CMC}$ bending (12); $\mathrm{r}=\mathrm{M}-\mathrm{S}$ stretching (12) $\alpha=$ MSM bending (12); $\delta=$ SMC bending (24); $\mathrm{t}=$ $\mathrm{CN}$ stretching (12); $\kappa=\mathrm{MCN}$ linear bending in a place through the model centre (12); $\lambda=$ MCN linear bending in a plane perpendicular to the one through the model centre (12) where the given designations $\mathrm{d}, \gamma, \mathrm{r}, \alpha, \delta, \mathrm{t}, \kappa, \lambda$ are various types of valance coordinates used for the construction of a set of independent symmetry coordinates for the $\left[\mathrm{Mo}_{4} \mathrm{~S}_{4}(\mathrm{CN})_{12}\right]^{8-}$ with $\mathrm{T}_{\mathrm{d}}$ symmetry.

The bands in the region of the $v(\mathrm{CN})$ vibrations $(2100$ $\mathrm{cm}^{-1}$ ) are easy to locate. It seems to be possible to distinguish between the Mo-S stretching vibrations less than $370 \mathrm{~cm}^{-1}(<$ $370 \mathrm{~cm}^{-1}$ ) on the one hand and the vibrations of the Mo-C-N linkage on the other hand (Mo-C stretching and $8 \mathrm{Mo}-\mathrm{CN}$ bending those lying at more than $370 \mathrm{~cm}^{-1}\left(>370 \mathrm{~cm}^{-1}\right)$, which 
are strongly coupled. $\mathrm{A}_{1}$ fundamentals are the strongest bands in the Raman and $\mathrm{T}_{2}$ bands the strongest bands in the IR.

There are $24 \delta$-type bending but only 12 combinations were used in the construction of the symmetry coordinates. The rest of them are present as redundancies, since all $\delta$-bending were included in the basis of the force field. In a similar way only 6 combinations of $12 \alpha$ bending are used in the symmetry coordinates. The agreement between the observed and calculated $v(\mathrm{Mo}-\mathrm{C})$ and $\delta(\mathrm{Mo}-\mathrm{CN})$ vibrations was not expected to be good as they are strongly coupled.

The measurements of intensities of the $v(\mathrm{CN})$ infrared bands is solution is of special interest. The integrated absorption coefficient $\mathrm{K}$ has been calculated from the molar extinction coefficient $\varepsilon_{\mathrm{m}}$ measured at the absorption maximum of the strong $v(\mathrm{CN})$ band and half-width under the assumption of Lorentz function band shape. The $v(\mathrm{CN})$ frequencies are dependents on the oxidation state of molybdenum. The correlation between the oxidation state and the $\mathrm{vCN}$ frequencies and their band intensities $\mathrm{c}$ be explained by the concept of donation and $\mathrm{M} \rightarrow \pi(\mathrm{CN})$ back-bonding. The intensity is a measure of the degree of $\mathrm{M}-\mathrm{C} \pi$-bonding i.e., of the increasing importance of value structure-II.

$$
\mathrm{L}_{\mathrm{n}} \mathrm{Mo}-\mathrm{C} \equiv \mathrm{N}: \quad \mathrm{L}_{\mathrm{n}} \mathrm{Mo}=\mathrm{CI}=\mathrm{C}:
$$

With an increasing number of (formal) Mo $4 d$ electrons, the valance structure II gains more importance. Therefore, the intensity per $\mathrm{CN}^{-}$ligand is higher in $\mathrm{K}_{6}\left[\mathrm{Mo}_{2}(\mathrm{III}) \mathrm{S}_{2}(\mathrm{CN})_{8}\right]$ than in the almost iso-structural $\mathrm{K}_{4}\left[\mathrm{Mo}_{2}(\mathrm{IV}) \mathrm{S}_{2}(\mathrm{CN})_{8}\right]$, but also higher in $\mathrm{K}_{8}\left[\mathrm{Mo}_{4}(\mathrm{III}) \mathrm{S}_{4}(\mathrm{CN})_{12}\right]$ than in $\mathrm{K}_{5}\left[\mathrm{Mo}_{3}(\mathrm{IV}) \mathrm{S}_{4}(\mathrm{CN})_{9}\right]$, where both having a comparable coordination of Mo which means $\left[\mathrm{Mo}(\mathrm{CN})_{3}\right]$ moieties are linked by Mo-Mo single bonds. The latter comparison is very rough since the variations involved are not of the same species.

The most interesting vibrations are those of the $\mathrm{Mo}_{4} \mathrm{~S}_{4}$ cube which can be classified according to the species

$v(\mathrm{Mo}-\mathrm{S}): \mathrm{A}_{1}+\mathrm{E}+\mathrm{T}_{1}+2 \mathrm{~T}_{2} ; \mathrm{v}(\mathrm{Mo}-\mathrm{Mo}): \mathrm{A}_{1}+\mathrm{E}+\mathrm{T}_{2}$

Electronic spectral data: The electronic spectrum is quite helpful to understand this core transformation from trimer to tetramer under this reducing atmosphere. Under the reducing environment of $\mathrm{Na} / \mathrm{Hg}$ or $\mathrm{Al}$-powder, the spectrum $\mathrm{A}$ of the starting material $\left[\mathrm{Mo}_{3} \mathrm{~S}_{4}(\mathrm{CN})_{9}\right]^{5-}$ charges from pattern (A) to (C). The electronic spectrum $\mathrm{C}$ of the fully reduced species $\left[\mathrm{Mo}_{3} \mathrm{~S}_{4}(\mathrm{CN})_{9}\right]^{7-}$ changed back to $\mathrm{A}$ on exposure of its reduced yellow solution to air. This quantitative conversion occurs via two distinct stage of oxidation showing two different isobestic point-(1) at $733 \mathrm{~nm}$ followed by $620 \mathrm{~nm}$ and (2) at $576 \mathrm{~nm}$. For fully reduced species we could not locate the appearance of band beyond $1100 \mathrm{~nm}$ due to the limitation of spectrophotometer used. UV-visible spectrum shows $\lambda_{\text {nm }}(\varepsilon): 1125$ (152), 660 (580), 500(sh), 388(sh), 316(14400); 270(32100); 220 (25000).

ESR-spectral study: The partially oxidized species $\mathbf{E}$ is solution with $\lambda_{\max }$ at $660 \mathrm{~nm}$ when vacuum dried and diluted with diamagnetic $\left[\mathrm{Mo}_{3} \mathrm{~S}_{4}(\mathrm{CN})_{9}\right]^{5-}$ complex ion show room temperature, ESR spectrum $\left(\mathrm{g}_{11}=2.073\right.$ and $\left.\mathrm{g}_{1}=1.985\right)$. The fully reduced species under similar treatment did not show any ESR signal. The reversal of the axial line shape of this ESR signal compared to that of $\left\{\mathrm{Mo}_{3}\right\}^{9}$ core may indicate the presence of $\left\{\mathrm{Mo}_{3}\right\}^{7}$ core in this half oxidized species ${ }^{6}$. The electron accepting property of water from the nitrogen atoms in the cyano ligated group in these species and stabilization of the reduced species by outer sphere complex formation with water may be responsible for the shift of half wave reduction potential to a less negative value compared to that in dimethyl sulphoxide.

Thus, a regular shift of half-wave potential to a less negative value for $\left\{\mathrm{Mo}_{3}\right\}^{6}$ to $\left\{\mathrm{Mo}_{3}\right\}^{7}$ and to a more positive one for $\left.\mathrm{Mo}_{3}\right\}^{6}$ to $\left\{\mathrm{Mo}_{3}\right\}^{5}$ steps due to increase of the percentage of water in dimethyl sulphoxide has been observed, demonstrating the role of a protic solvent in cyanoligated species ${ }^{21,22}$.

Electrochemical study: Cyclic voltammogram of $\mathrm{K}_{5}\left[\mathrm{Mo}_{3} \mathrm{~S}_{4}(\mathrm{CN})_{9}\right]$ in water with different supporting electrolyte compositions $\left(\mathrm{KCl}, \mathrm{KOH}-\mathrm{KCN}, \mathrm{KOH}-\mathrm{KCN}-\mathrm{K}_{2}\left[\mathrm{Zn}(\mathrm{CN})_{4}\right]\right.$ are shown in Fig. 1(A-F). The reported E1/2 $=-1.49 \mathrm{~V} v s$ NHE for one electron reduction of $\mathrm{K}_{5}\left[\mathrm{Mo}_{3} \mathrm{~S}_{4}(\mathrm{CN})_{9}\right]$ in $\mathrm{DMSO}^{9}$ is drastically shifted to $-0.74 \mathrm{~V}$ using $\mathrm{KCl}(\Delta \mathrm{E}=100 \mathrm{mV})$ and $\mathrm{KOH}-$ $\mathrm{KCN}(\Delta \mathrm{E}=80 \mathrm{mV})$ as supporting electrolyte, respectively. In the latter case, this two more successive reduction peak potentials appeared around -1.20 and $-1.40 \mathrm{~V}$, respectively.

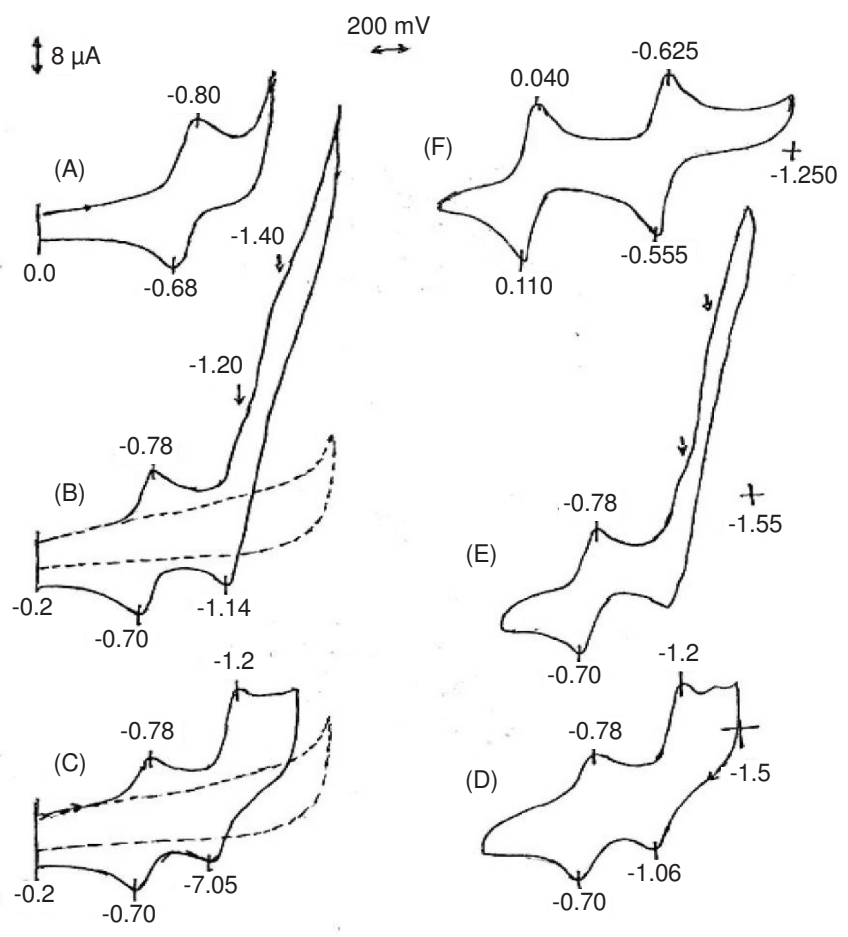

Fig. 1. Cyclic voltammograms of $0.98 \mathrm{mM} \mathrm{K}_{5}\left[\mathrm{Mo}_{3} \mathrm{~S}_{4}(\mathrm{CN})_{9}\right]$ in different supporting electrolyte composotions: (A), $\mathrm{KCl}$; (B), $\mathrm{KOH}-\mathrm{KCN}$; (C) $\mathrm{KOH}-\mathrm{KCN}-\mathrm{K}_{2}\left[\mathrm{Zn}(\mathrm{CN})_{4}\right]$. Broken lines in $\mathrm{B}$ and $\mathrm{C}$ were blank scans. Voltammograms of chemically generated $0.98 \mathrm{mM}$ $\left[\mathrm{Mo}_{3} \mathrm{~S}_{4}\left(\mathrm{CN}_{9}\right)\right]^{7-}$ by zinc (D) and aluminium (E) (see text of electrolyte compositions). Voltammogram of $1 \mathrm{mM}$ solution of $\left[\mathrm{Mo}_{4} \mathrm{~S}_{4}(\mathrm{CN})_{12}\right]^{8-}$ in $0.5 \mathrm{M} \mathrm{KCl}(\mathrm{F})$. All scan rates, $100 \mathrm{mV} \mathrm{s}^{-1}$ at $25 \pm 1{ }^{\circ} \mathrm{C}$

When $\mathrm{KOH}-\mathrm{KCN}-\mathrm{K}_{2}\left[\mathrm{Zn}(\mathrm{CN})_{4}\right]$ combined supporting electrolyte was used the appearance of second reduction process became by the third irreversible reduction. The quasi-reversible nature of the first reduction step in $\mathrm{KCl}$ changed to the fully reversible form in $\mathrm{KOH}-\mathrm{KCN}$ supporting electrolyte. All the reductions steps are diffusion controlled in nature. 
Anaerobic chemical reduction of $\mathrm{K}_{5}\left[\mathrm{Mo}_{3} \mathrm{~S}_{4}(\mathrm{CN})_{9}\right]$ in $\mathrm{KOH}-\mathrm{KCN}$ medium by $\mathrm{Zn}$ powder led to the change of colour from bright green to yellow via olive-green. Oxidative scan of this species (resting potential at $-1.5 \mathrm{~V}$ ) showed an indentical voltammogram to that observed in the reductive scan (resting potentiat at $0.00 \mathrm{~V}$ ) for $\mathrm{K}_{5}\left[\mathrm{Mo}_{3} \mathrm{~S}_{4}(\mathrm{CN})_{9}\right]$ with $\mathrm{KOH}-\mathrm{KCN}$ $\mathrm{K}_{2}\left[\mathrm{Zn}(\mathrm{CN})_{4}\right]$ as the supporting electrolyte. Fig. 1(C,D). Then reduction of the starting material $\left.\mathrm{K}_{5}\left[\mathrm{Mo}_{3} \mathrm{~S}_{4} \mathrm{CN}\right)_{9}\right]$ was accomplished by the using aluminium powder instead of zinc powder, the reverse scan (oxidative, resting potential at $-1.55 \mathrm{~V}$ ) of the yellow solution was identical to what the observed in the reductive scan of $\mathrm{K}_{5}\left[\mathrm{Mo}_{3} \mathrm{~S}_{4}(\mathrm{CN})_{9}\right]$ with $\mathrm{KOH}-\mathrm{KCN}$ as supporting electrolyte (Fig. 1B,E).

For a trinuclear cluster having $d^{6}$ electronic configuration, the electrons responsible for three metal-metal bonds will be accommodated in $1 \mathrm{a}_{1}^{2}-1 \mathrm{e}^{4}$ orbitals $^{3}$. The diamagnetism of these complexes can thus readily be explained using this quantitative M.O. Scheme (Fig. 2).

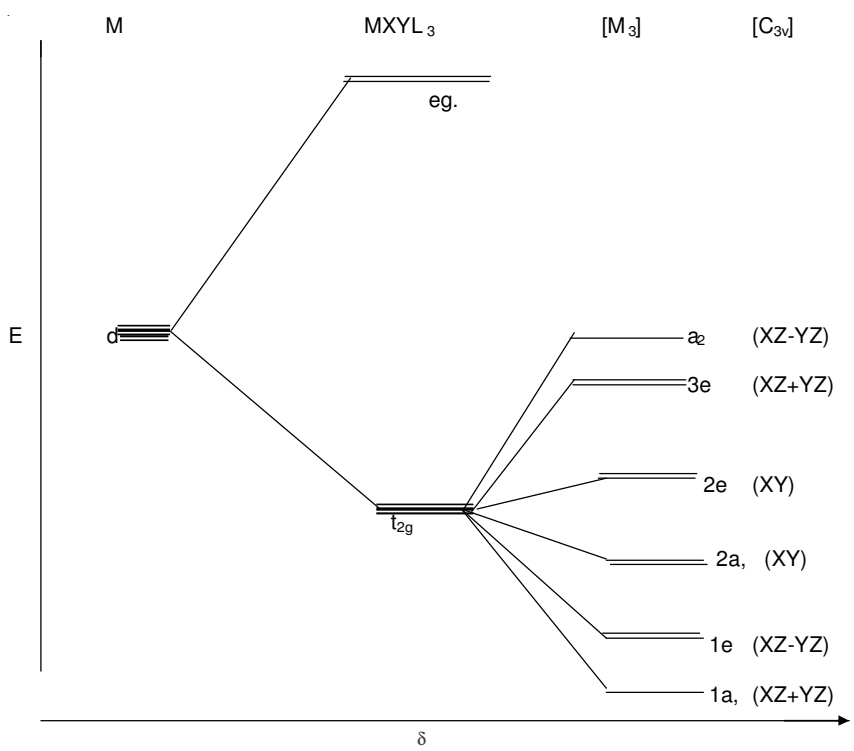

Fig. 2. MO Scheme for the $\mathrm{Mo}_{3}$ system of $\left\{\mathrm{Mo}_{3} \mathrm{~S}_{4}\right\}^{4+}$-core

Interesting lying non-bonding molecular orbital, the low $2 \mathrm{a}_{1}$ under reducing environments may be populated, thus showing the possibilities of having $\left\{\mathrm{Mo}_{3} \mathrm{~S}_{4}\right\}^{4+}$ core with $d^{7}$ or $d^{8}$ electronic configuration. The relative energies of these orbitals, suggest that the absorption within these orbitals will occur under visible region and these transitions are symmetry allowed. They should have higher intensities than the $d$-d transition like $\mathrm{L} \rightarrow \mathrm{M}$ and $\mathrm{M} \rightarrow \mathrm{L}$ are expected to occur only at higher energy. It is interesting to take a note that on going from $\left\{\mathrm{Mo}_{3}\right\}^{6}$ to $\left\{\mathrm{Mo}_{3}\right\}^{8}$ configuration, the extra two electrons are populated in mainly non-bonding orbital $2 \mathrm{a}_{1}$ with respect to the metal-metal bond. If by any chemical means, extra electrons are being populated to the next anti-bonding orbitals $2 \mathrm{e}$ and so on in relation to the $\mathrm{M}-\mathrm{M}$ bond, the $\mathrm{M}_{3}$-core will be destabilized. Thus, with the electronic configuration $\left\{\mathrm{Mo}_{3}\right\}^{9}$, each metal atom now acquires one electrons more and for its stabilization core rearrangement like

$$
4\left\{\mathrm{Mo}_{3}\right\}^{9} \longrightarrow 3\left\{\mathrm{Mo}_{4}\right\}^{12}
$$

should occur leading to the formation of a complete cubane core like $3\left\{\mathrm{Mo}_{4}\right\}^{4+}$.
The electron balanced reaction can be summarized as follows:

$$
\begin{aligned}
& 4\left[\mathrm{~K}_{5} \mathrm{Mo}_{3} \mathrm{~S}_{4}(\mathrm{CN})_{9}\right]+12 \mathrm{Na}-\mathrm{Hg} \rightarrow 4\left[\mathrm{~K}_{5} \mathrm{Na}_{3}\left[\mathrm{Mo}_{3} \mathrm{~S}_{4}(\mathrm{CN})_{9}\right]\right] \\
& 4 \mathrm{~K}_{5} \mathrm{Na}_{3}\left[\mathrm{Mo}_{3} \mathrm{~S}_{4}(\mathrm{CN})_{9}\right] \rightarrow 2 \mathrm{~K}_{8}\left[\mathrm{Mo}_{4} \mathrm{~S}_{4}(\mathrm{CN})_{12}+4 \mathrm{Na}_{2} \mathrm{~S}\right. \\
& +\mathrm{K}_{4} \mathrm{Na}_{4}\left[\mathrm{Mo}_{4} \mathrm{~S}_{4}(\mathrm{CN})_{12}\right] \\
& \mathrm{K}_{4} \mathrm{Na}_{4}\left[\mathrm{Mo}_{4} \mathrm{~S}_{4}(\mathrm{CN})_{12}\right]+4 \mathrm{KCN} \rightarrow \mathrm{K}_{8}\left[\mathrm{Mo}_{4} \mathrm{~S}_{4}(\mathrm{CN})_{12}\right]+4 \mathrm{NaCN} \\
& 4 \mathrm{~K}_{5}\left[\mathrm{Mo}_{3} \mathrm{~S}_{4}(\mathrm{CN})_{9}\right]+12 \mathrm{Na}-\mathrm{Hg}+4 \mathrm{KCN} \rightarrow 3 \mathrm{~K}_{8}\left[\mathrm{Mo}_{4} \mathrm{~S}_{4}(\mathrm{CN})_{12}\right. \\
& +4 \mathrm{NaCN}+4 \mathrm{Na}_{2} \mathrm{~S} \\
& 4 \mathrm{~K}_{5}\left[\mathrm{Mo}_{3} \mathrm{~S}_{4}(\mathrm{CN})_{9}\right]+4 \mathrm{Al}+16 \mathrm{KOH} \underset{70{ }^{\circ} \mathrm{C}}{\stackrel{\text { Water }}{\longrightarrow}} \\
& 3 \mathrm{~K}_{8}\left[\mathrm{Mo}_{4} \mathrm{~S}_{4}(\mathrm{CN})_{12}\right]+4 \mathrm{~K}_{2} \mathrm{~S}+4 \mathrm{~K}\left[\mathrm{Al}(\mathrm{OH})_{4}\right]
\end{aligned}
$$

A model reaction to achieve such core conversion which has been made under the solid reaction state also as follows:

$$
\begin{aligned}
& 4 \mathrm{~K}_{5}\left[\mathrm{Mo}_{3} \mathrm{~S}_{4}(\mathrm{CN})_{9}\right]+8 \mathrm{KCN} \underset{\mathrm{KSCN}, 250^{\circ} \mathrm{C}}{\stackrel{\text { Fused }}{\longrightarrow}} \\
& 3 \mathrm{~K}_{8}\left[\mathrm{Mo}_{4} \mathrm{~S}_{4}(\mathrm{CN})_{12}\right]+4 \mathrm{KSCN}+2(\mathrm{CN})_{2}
\end{aligned}
$$

The cyclic voltammogram of the isolated compound by this process as shown in Fig. $1 \mathrm{~F}$ is identical to that of $\mathrm{K}_{8}\left[\mathrm{Mo}_{4} \mathrm{~S}_{4}(\mathrm{CN})_{12}\right]$ obtained by the authentic method.

The X-ray powder diffraction data of (2) synthesized by adopting the alternative route are almost matching to that reported in literature ${ }^{20}$. The similarities between the model substances for the ferredoxins and the complexes under study regarding their formal electron-transfer properties are striking. Since all known cyanothiomolybdates undergoes reversible electrochemical redox reaction.

It is important to realize that $\left[\mathrm{Mo}_{3} \mathrm{~S}_{4}(\mathrm{CN})_{9}\right]^{5-}$ and $\left[\mathrm{Mo}_{4} \mathrm{~S}_{4}(\mathrm{CN})_{12}\right]^{8-}$ have been obtained by the reaction of amorphous $\mathrm{MoS}_{3}$ with excess of $\mathrm{KCN}$ in aqueous solution. Where the major product was $\left[\mathrm{Mo}_{3} \mathrm{~S}_{4}(\mathrm{CN})_{9}\right]^{5-}$ (yield $=10 \%$ based on the starting material). The tetramer complex ion $\left[\mathrm{Mo}_{4} \mathrm{~S}_{4}(\mathrm{CN})_{12}\right]^{8-}$ was obtained as a by-product of the reaction in the very low yield (Can $1.25 \%$ based on starting material). The high yield of $\mathbf{1}$ and very low yield of $\mathbf{2}$ suggest that the trinuclear cluster units are already present in the amophous $\mathrm{MoS}_{3}$ a part of which gets slowly convert to the tetramer unit 2 under the available reducing atmosphere of $\mathrm{KCN}^{20}$. The phenomenon of this core conversion has also been confirmed experimentally by the another that on reducing the aqueous solution of $\mathbf{1}$ with $\mathrm{KOH}$ and $\mathrm{Al}$-powder it generates $\mathbf{2}$ in near quantitative yield.

\section{Conclusion}

Tuning of reduction potential of $\mathrm{K}_{5}\left[\mathrm{Mo}_{3} \mathrm{~S}_{4}(\mathrm{CN})_{9}\right]$ with $\left\{\mathrm{Mo}_{3}\right\}^{6}$ core in aqueous medium led to the media-dependent electron transfer steps using $\mathrm{KOH}-\mathrm{KCN}-\mathrm{K}_{2}\left[\mathrm{Zn}(\mathrm{CN})_{4}\right]$ ternary system as supporting electrolyte. We have identified the species containing $\left\{\mathrm{Mo}_{3}\right\}^{8}$ cores by electro chemicals and spectroscopic techniques. It is important to note, that the unstable reduced $\left\{\mathrm{Mo}_{3}(\mathrm{III})\right\}^{9+}$ core is rearranged to yield an electron-precise tetrahedral $\left\{\mathrm{Mo}_{3}(\mathrm{III})\right\}^{12+}$ core containing $\left[\mathrm{Mo}_{4}(\mathrm{III}) \mathrm{S}_{4}(\mathrm{CN})_{12}\right]^{8-}$ ion by the core expansion: $4\left\{\mathrm{Mo}_{3}(\mathrm{III})\right\}^{9+}$ $\rightarrow 3\left\{\mathrm{Mo}_{4}(\mathrm{III})\right\}^{12+}$ according to the electron-precise cluster rule interesting, the fully reduced species $\mathrm{K}_{8}\left[\mathrm{Mo}_{4} \mathrm{~S}_{4}(\mathrm{CN})_{12}\right]$ on subject to oxidation using $\mathrm{H}_{2} \mathrm{O}_{2}$ or $\mathrm{Cl}_{2}$-water, it does not revert back to the oxidized starting material $\mathrm{K}_{5}\left[\mathrm{Mo}_{3} \mathrm{~S}_{4}(\mathrm{CN})_{9}\right]$. The oxidation responses to the generation of oxo-species of $\mathrm{Mo}_{3}-$ trimer or $\mathrm{Mo}_{2}$-dimer core. 


\section{ACKNOWLEDGEMENTS}

The authors expressed their sincere gratitude to Prof. S. Sarkar, Head, Chemistry Department, I.I.T. Kanpur for his valuable suggestions. Thanks are also due to Dr. S.K. Das and Dr. P.K. Chaudhury for the measurement of some valuable data.

\section{REFERENCES}

1. F.A. Cotton, Inorg. Chem., 3, 1217 (1964).

2. A.J. Bard and Faulkner, Electrochemical Methods, Wiley, New York (1980).

3. B.E. Bursten, F.A. Cotton, M.B. Hall and R.C. Najjar, J. Am. Chem. Soc., 104, 302 (1982).

4. (a) F.A. Cotton and X. Fung, Inorg. Chem., 30, 3666 (1991); (b) D.T. Richews and A.G. Sykes, Inorg. Chem., 21, 418 (1982); (c) M.T. Paffett and F.C. Asnon, Inorg. Chem., 22, 1547 (1983).

5. (a) Y. Ide and T. Shibahara, Inorg. Chem., 46, 357 (2007); (b) T Yamauchi, H. Takagi, Shibahara and H. Akashi, Inorg. Chem., 45, 5429 (2006).

6. (a) H. Akashi, K. Isobe and T. Shibahara, Inorg. Chem., 44, 3494 (2005); (b) Y. Ide, M. Sasaki, M. Maeyama and T. Shibahara, Inorg. Chem., 43, 602 (2004).

7. T. Shibahara and H. Kuroya, Polyhedron, 5, 357 (1986); T. Shibahara, H. Akashi and H. Kuroya, J. Am. Chem. Soc., 108, 1342 (1986).

8. N.C. Howladir, G.P. Haight, T.W. Hambley, G.A. Law Rank, K.M. Rahmoiller and M.K. Show, Aust. J. Chem., 36, 377 (1983).

9. K. Weighardt, W. Herrman, A. Miller; W. Elzner and Zimmermann, Z. Naturforsch, 39B, 876 (1984).
10. T. Shibahara, M. Tsuboi, S. Nakaska and Y. Ide, Inorg. Chem., 42, 935 (2003); S.-B. Yu, M. Droege, B. Segal, S.-H. Kim, T. Sanderson and A.D. Watson, Inorg. Chem., 39, 1325 (2000).

11. T. Shibahara and H. Kuroya, Abstract of Papers, International Mini Conference for Young Chemist in Tokyo-Mamo cyclic and Coordination Chemistry, July (1987).

12. T. Shibahara, H. Akashi and H. Kuroya, J. Am. Chem. Soc., 110, 3313 (1988).

13. T. Shibahara, Presented at the Japanese Chemical Society Meeting at Koyota, Japan, April, pp. 4-426 (1986).

14. T. Shibaha, Proceeding of the 26th International Coordination Chemistry Conference, Oporto, Portugal, Paper A 27 (1988)

15. T. Shibahara, T. Yamamoto, H. Kanadani and H. Kuroya, J. Am. Chem. Soc., 109, 3495 (1987).

16. G. Christou, C.D. Garner, F.E. Maabs and T.J. King, J. Chem. Soc. Chem. Commun., 740 (1978).

17. S.R. Acott, G. Christou, C.D. Garner, T.G. Kings, F.E. Mabbs and R.M. Miller, Inorg. Chem. Acta, 35, L337 (1979).

18. G. Christou and C.D. Garner, J. Chem. Soc. Dalton Trans., 2354 (1980).

19. (a) T. Shibahara, E. Kawano, M. Okano, M. Nishi and H. Kuroya, Chem. Lett., 827 (1986); (b) A. Muller and U. Reinsch, Angew. Chem. Int. Ed. Engl., 19, 72 (1980).

20. A. Miller, R. Jostes, W. Eltzner, E. Diemann, H. Bogge M. Zimmermann, M. Dartmann and B.N. Cyvin, Inorg. Chem., 24, 2872 (1985).

21. (a) P.K. Mascharak, Inorg Chem., 25, 245 (1986); (b) G. Sakane, K. Hashimoto, M. Takashi, M. Takede and T. Shibahara, Inorg. Chem., 37, 4231 (1998).

22. S. Sarkar, R. Sah, P.K. Chaudhary, R. Maiti and S.K. Das, Proc. Indian Acad. Sci. (Chem. Sci.), 107, 355 (1995). 